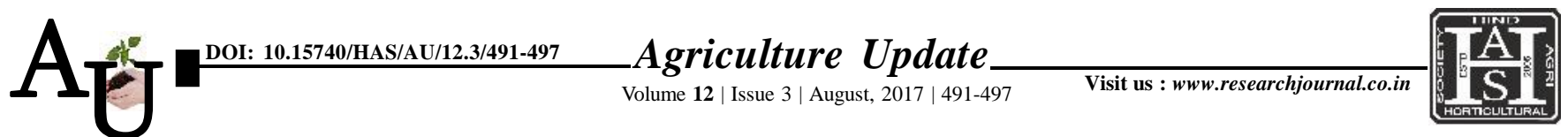

D e ISSN-0976-6847

A Review :

\title{
Environmental degradation and agricultural sustainability
}

\section{RITAMBHARA SINGH}

Article Chronicle: Received :

22.06.2017;

Accepted :

20.07.2017

KEY Words:

Biotechnology, Micro irrigation, Vertical farming, Biofertilizers, Magnetic agriculture, Nanotechnology, Precision farming

Author for correspondence :

\section{RITAMBHARA SINGH}

Department of

Agribusiness Economics

and Policies,

International

Agribusiness

Management Institute,

Anand Agricultural

University, ANAND

(GUJARAT) INDIA

Email:singhR@aau.in
SUMMARY : Environmental degradation means degradation or deterioration of the environment as a result of degradation of soil, water and air resources, destruction of habitats and ecosystems, etc. Our activities in agriculture have led to a decline in soil quality at several places. The anthropogenic activities in agriculture have also led to climate change, in the form of rising temperatures, unusual rainfall, drought and other havocs which impact food availability for not only today but also tomorrow. In order to achieve the desired yields to meet the needs of ever growing population; ensure food and nutritional security to all, Indian agriculture should move towards wide adoption of mix of technologies like biotechnology, precision farming, magnetic agriculture, vertical farming, micro irrigation systems, nanotechnology, etc, which help in enhancing yield without disturbing the soil health, arrest environmental degradation and achieve agricultural sustainability.

How to cite this article : Singh, Ritambhara (2017). Environmental degradation and agricultural sustainability. Agric. Update, 12(3): 491-497; DOI : 10.15740/HAS/AU/12.3/491-497. 